\title{
Pengaruh Pemberian Ekstrak Etanol 70\% Daun Binahong (Anredera scandens (L.) Moq.) terhadap Makroskopik dan Biokimia Ginjal Mencit Jantan Galur Balb/C
}

\author{
Samirana, P.O. ${ }^{1}$, Swastini, D.A. ${ }^{1}$, Satriani, N. W. ${ }^{1}$ \\ ${ }^{1}$ Program Studi Farmasi Fakultas Matematika dan Ilmu Pengetahuan Alam Universitas Udayana \\ Korespondensi: Putu Oka Samirana \\ Program Studi Farmasi Fakultas Matematika dan Ilmu Pengetahuan Alam Universitas Udayana \\ Jalan Kampus Unud-Jimbaran-Bali, Indonesia 80361 Telp/Fax: 0361-703837 \\ Email: oka_samirana@unud.ac.id
}

\begin{abstract}
ABSTRAK
Anredera scandens (L.) Moq. atau binahong merupakan tanaman yang bagian daunnya telah terbukti secara ilmiah memiliki aktivitas sebagai antitukak. Tujuan penelitian ini adalah untuk mengetahui dan mendeskripsikan pengaruh ekstrak etanol 70\% daun A. scandens (L.) Moq. terhadap makroskopik ginjal dilihat dari parameter berat dan volume, serta biokimia ginjal ginjal dilihat dari parameter kadar BUN dan kreatinin darah.

Simplisia dan ekstrak uji terlebih dahulu diukur kadar airnya. Uji pengaruh ekstrak etanol $70 \%$ daun A. scandens (L.) Moq. pada ginjal dilakukan pada mencit jantan galur Balb/C secara peroral sekali sehari selama 30 hari. Pengukuran berat dan volume ginjal, kadar BUN dan kreatinin dilakukan pada akhir penelitian. Data parametrik dianalisis dengan ANOVA-one way, dan data nonparametrik dianalisis dengan Kruskall-Wallis dan uji Mann-Whitney.

Pengukuran kadar air simplisia dan ekstrak uji menunjukkan hasil yang memenuhi standar Farmakope Herbal Indonesia. Pemberian ekstrak etanol 70\% daun A. scandens (L.) Moq. selama 30 hari, secara statistik tidak memberikan pengaruh yang signifikan terhadap makroskopik ginjal yang dilihat dari parameter berat dan volume ginjal serta biokimia ginjal dilihat dari kadar BUN dan kreatinin.
\end{abstract}

Keywords: volume, berat, BUN, kreatinin, ginjal, Anredera scandens

\section{ABSTRACT}

Anredera scandens (L.) Moq. or binahong is a plant whose leaf part has been scientifically proven to have activity as an antiulcer. The purpose of this research is to know and describe the effect of ethanol extract $70 \%$ leaf A. scandens (L.) Moq. on macroscopic renal seen from the parameters of renal weight and volume, and renal kidney biochemistry seen from the parameters of BUN content and blood creatinine.

Powder and extract first measured its water content. Test effect of ethanol extract $70 \%$ leaf $A$. scandens (L.) Moq. in the kidney was performed on male Balb / C mice once daily for 30 days. Measurements of renal weight and volume, BUN and creatinine levels were performed at the end of the study. Parametric data was analyzed by ANOVA-one way, and nonparametric data was analyzed by Kruskall-Wallis and Mann-Whitney test.

The measurement of powdered and extract water content showed results that meet the standard of Herbal Pharmacopoeia Indonesia. Provision of ethanol extract $70 \%$ leaf A. scandens (L.) Moq. for 30 days, did not statistically give significant effect to renal macroscopic seen from renal weight and volume parameter and renal biochemistry seen from BUN and creatinine levels.

Keywords: volume, weight, BUN, creatinine, kidney, Anredera scandens 


\section{PENDAHULUAN}

Anredera scandens (L.) Moq. atau binahong adalah tanaman yang bagian daunnya dimanfaatkan oleh masyarakat untuk mengobati luka setelah melahirkan, luka kitan, radang usus, wasir, maag, meningkatkan daya tubuh, memperkuat daya tahan sel terhadap infeksi sekaligus memperbaiki sel yang rusak, melancarkan dan menormalkan peredaran darah serta tekanan darah, mencegah stroke, dan mengatasi diabetes (Hariana, 2013).

Aktivitas farmakologi daun A. scandens (L.) Moq. telah dibuktikan melalui beberapa penelitian ilmiah. Melalui pemberian secaara peroral ekstrak etanol daun A. scandens (L.) Moq. pada tikus jantan Sprague Dawley, dilaporkan memiliki aktivitas antitukak dengan dosis efektif $50 \%\left(\mathrm{ED}_{50}\right) 356 \mathrm{mg} / \mathrm{Kg} \mathrm{BB}$ dan antiinflamasi dengan $\mathrm{ED}_{50}$ sebesar 382 $\mathrm{mg} / \mathrm{kgBB}$ atau setara dengan $0,5 \mathrm{~g} / \mathrm{Kg} \mathrm{BB}$ pada mencit (Samirana et al., 2014; Feybriyanti, 2011).

Berdasarkan penelitian tersebut, ekstrak daun A. scandens (L.) Moq. berpotensi untuk dikembangkan menjadi obat herbal terstandar, untuk itu perlu adanya data keamanan dari ekstrak ini mengingat salah satu syarat obat herbal terstandar adalah adanya data keamanan secara in vivo yang diperoleh melalui uji toksisitas oral (BPOM, 2004).

Pengaruh pemberian ekstrak etanol daun A. scandens (L.) Moq. pada hati telah dilakukan sebelumnya pada mencit jantan galur Balb/C. Berdasarkan uji toksisitas akut diperoleh nilai $\mathrm{LD}_{50}$ sebesar $23,78 \mathrm{~g} / \mathrm{Kg}$ yang dikategorikan ke dalam relatively harmless. Pada uji toksisitas subkronis diperoleh bahwa pemberian ekstrak etanol daun A. scandens (L.) Moq. toksik terhadap sel hati Karena menyebaabkan degenerasi dan nekrosis sel hati (Daramita, 2011).

Namun, berdasarkan penelitian di atas, pengaruh pemberian ekstrak etanol pada organ ginjal belum dilakukan A. scandens (L.) Moq., mengingat syarat keamanan sediaan oral sesuai dengan Pedoman Uji Toksisitas Nonklinik secara In vivo adalah dilakukannya pengamatan minimal pada dua organ hati dan ginjal hewan uji. Hal ini berkaitan dengan fungsi organ tersebut sebagai pemetabolisme dan pengekskresi. (Campbell et al., 2003).

Parameter keamanan pemberian ekstrak etanol A. scandens (L.) Moq. pada ginjal yang diamati dalam penelitian ini adalah makroskopis meliputi berat dan volume, serta biokimia darah meliputi pengukuuran kadar BUN dan kreatinin serum. Senyawa yang toksik terhadap ginjal atau bersifat nefrotoksik akan memberikan pengaruh terhadap makroskopis ginjal adanya perubahan berat dan volume ginjal dibandingkan dengan kondisi normal. Parameter biokimia darah yang menjadi marker spesifik fungsi ginjal adalah kadar BUN (Blood Urea Nitrogen) dan kreatinin. Urea merupakan produk akhir katabolisme protein serta asam amino, sedangkan kreatinin merupakan hasil metabolisme dari kreatin fosfat otot yang jalur ekskresi utamanya melalui ginjal, jika kadarnya di dalam darah lebih tinggi dibandingkan dengan kondisi normal, maka mengindikasikan terjadinya penurunan fungsi ginjal (Gowda et al., 2010). Berdasarkan hal tersebut, maka perlu dilakukan penelitian terhadap pengaruh pemberian ekstrak etanol $A$. scandens (L.) Moq. terhadap ginjal dilihat dari parameter makroskopis yaitu berat dan volume serta biokimia yaitu BUN dan kreatinin darah.

\section{METODE PENELITIAN}

\subsection{Bahan Penelitian}

Serbuk simplisia daun A. scandens (L.) Moq. yang diperoleh dari CV. Merapi Farma Herbal, Hargobinangun, Pakem, Sleman, Yogyakarta; etanol $70 \% \quad\left(\right.$ Bratachem $\left.^{\circledR}\right)$ yang berderajat teknis, akuades $\left(\right.$ Bratachem $\left.^{\circledR}\right)$; Tween 80 $\left(\right.$ Merck $\left.^{\circledR}\right)$ berderajat pro analisis; eter; dan reagen Cobas ${ }^{\circledR}$ c 501 Analyzer

\subsection{Alat Penelitian}

Rotavapor, alat-alat gelas, spuite, mikroskop cahaya Olympus, Cobas ${ }^{\circledR}$ c 501 Analyzer, tabung eppendorf, sentrifugator, sonde, krus porselin, oven, dan timbangan analitik.

\subsection{Prosedur Penelitian}

Penelitian ini menggunakan metode penelitian eksperimental laboratorik dan dilakukan melalui beberapa tahap, yaitu: 
1) Penetapan kadar air serbuk dari daun $A$. scandens (L.) Moq. dengan metode gravimetri. Kadar air dalam bahan ditentukan dengan menggunakan persamaan 1 .

$$
\% \text { Kadar air }=\frac{\text { berat }_{a w a l} \text {-berat }_{\text {akhi் }}}{\text { berat }_{\text {awal }}} \times 100 \%
$$

2) Pembuatan ekstrak daun A. scandens (L.) Moq.

Sebanyak 200 gram serbuk simplisia daun A. scandens (L.) Moq. dimaserasi dengan $2 \mathrm{~L}$ etanol $70 \%$.

3) Penetapan Kadar Air ekstrak daun $A$. scandens (L.) Moq. dengan metode gravimetri. Kadar air dalam bahan ditentukan dengan menggunakan persamaan 1 .

4) Uji pengaruh pemberian ekstrak etanol $70 \%$ daun binahong (A. scandens (L.) Moq.)

Terhadap gambaran makroskopik dan biokimia ginjal mencit jantan galur Balb/C dilakukan pada lima kelompok mencit (5 ekor per kelompok). K0 (Kontrol normal) diberikan akuades, K1 (Kontrol pembawa) diberikan 5\% Tween 80, K2 kelompok dosis 0,5 g/Kg BB, K3 kelompok dosis $0,75 \mathrm{~g} / \mathrm{Kg} \mathrm{BB}$, dan $\mathrm{K} 4$ kelompok dosis $1 \mathrm{~g} / \mathrm{Kg} \quad \mathrm{BB}$. Perlakuan dilakukan setiap hari secara peroral selama 30 hari. Pengukuran volume dan berat ginjal serta pengukuran kadar BUN dan kreatinin pada serum dilakukan pada hari ke 31 .

5) Pengumpulan Data

a) Pemeriksaan Gambaran Makroskopis

Mengukur volume ginjal dengan cara memasukkan organ ginjal ke dalam gelas ukur yang telah diisi akuades. Volume ginjal yang diukur adalah kenaikan permukaan ginjal pada gelas ukur menggunakan pipet ukur $0,5 \mathrm{~mL}$. Mengukur berat ginjal dengan cara menimbang ginjal mencit

b) Pemeriksaan Biokimia Darah

Pengambilan darah dilakukan oleh dokter hewan dari Fakultas Kedokteran Hewan Universitas Udayana. Mencit diambil darahnya melalui jantung setelah dianestesi menggunakan pelarut eter secara inhalasi. Darah ditampung ke dalam tabung eppendrof melalui dinding tabung, didiamkan selama 45 menit hingga mengendap, kemudian disentrifugasi dengan kecepatan $3500 \mathrm{rpm}$ selama 3 menit dan diambil supernatannya (serum). Penetapan kadar BUN dan Kreatinin darah dilakukan oleh pihak Laboratorium Patologi Klinik, Rumah Sakit Umum Pusat Sanglah, Denpasar. Kadar BUN dan kreatinin darah diukur dengan menggunakan Cobas ${ }^{\circledR} \mathrm{c}$ 501 Analyzer. Langkah penetapan kadar BUN dan kreatinin darah adalah sampel dengan volume minimal $50 \mu \mathrm{L}$ dimasukkan ke dalam tabung sampel dan secara terpisah reagen Cobas ${ }^{\circledR}$ c 501 Analyzer dimasukkan ke dalam tempat sampel selanjutnya pencampuran antara sampel dan reagen dilakukan secara automatis, pembacaan absorbansi hasil reaksi tersebut dilakukan pada panjang gelombang $340 \mathrm{~nm}$.

6) Analisis data

Data makroskopik ginjal yaitu berat dan volume ginjal serta kadar BUN dan kreatinin darah masing-masing secara terpisah diuji normalitasnya dengan metode Saphiro Wilk dan homogenitasnya dengan metode Levene test, data dinyatakan terdistribusi secara normal dan homogen apabila $p>0,05$. Data yang memenuhi kriteria normalitas dan homogenitas, dilanjutkan dengan analisis parametrik dengan analisis ANOVA-one way dengan nilai kepercayaan $95 \%$ untuk menentukan perbedaan pada kelompok perlakuan.

\section{HASIL DAN PEMBAHASAN}

\subsection{Kadar Air Serbuk Simplisia}

Hasil penetapan kadar air rata-rata serbuk simplisia daun A. scandens (L.) Moq. dalam penelitian ini adalah 7,69 $\pm 0,35 \%$. Kadar tersebut sudah memenuhi syarat kadar air simplisia daun A. scandens (L.) Moq yang ditetapkan Farmakope Herbal Indonesia yaitu kurang dari 10\% (Depkes RI, 2011). Kadar air simplisia harus memenuhi ketentuan yang ditetapkan, hal ini bertujuan untuk mengurangi kerusakan simplisia akibat kadar air yang tinggi, karena air merupakan media pertumbuhan yang baik untuk jamur dan mikroba patogen lainnya (Katno, 2008).

\subsection{Ekstraksi}

Rendemen yang diperoleh dari proses ekstraksi dalam penelitian ini adalah 19,22\%. Perolehan rendemen tersebut sudah memenuhi syarat rendemen ekstrak simplisia daun A. scandens (L.) Moq. yang ditetapkan Farmakope Herbal Indonesia yaitu tidak kurang dari 11,91\% (Depkes RI, 2011). 


\section{Samirana, dkk.}

Jurnal Farmasi Udayana, Vol6, No.2, Tahun 2017, 28-35

\subsection{Kadar Air Ekstrak}

Hasil penetapan kadar air rata-rata ekstrak etanol $70 \%$ daun A. scandens (L.) Moq. yang digunakan dalam penelitian ini adalah $4,34 \pm 0,18 \%$. Kadar tersebut sudah memenuhi syarat kadar air ekstrak daun A. scandens (L.) Moq. yang ditetapkan Farmakope Herbal Indonesia yaitu tidak lebih dari 8,85\% (Depkes RI, 2011).

\subsection{Pengaruh Pemberian Ekstrak Etanol 70\% Daun Binahong (A. scandens (L.) Moq.) terhadap Gambaran Makroskopik Ginjal Mencit Jantan Galur Balb/C}

Volume dan berat organ ginjal diukur pada hari ke-31, yaitu pada akhir penelitian. Berat organ ginjal ditentukan dengan menimbang ginjal dan volume ginjal diukur dengan cara memasukkan ginjal pada gelas ukur yang telah berisi akuades, dan ukur volume kenaikan akuades setelah ginjal dimasukkan. Data berat dan volume rata-rata ginjal ditampilkan pada tabel 3.1, yang merupakan rata-rata antara ginjal kiri dan kanan. Pengukuran berat dan volume organ merupakan gambaran awal untuk memprediksi toksisitas, induksi enzim, dan gangguan fisiologis pada organ target. Gambaran berat organ merupakan parameter awal untuk memprediksi toksisitas sampel yang diuji, sebelum dilanjutkan dengan pemeriksaan secara mikroskopik (Sellers et al., 2007; Michael et al., 2007; Jothy et al., 2011; Ping et al., 2013; Nirogi et al., 2014).

Data volume dan berat organ ginjal semua kelompok perlakuan diuji terlebih dahulu dengan metode Shapiro-Wilk untuk melihat normalitas data dan Levene test untuk melihat homogenitas data. Berdasarkan uji tersebut, data yang diperoleh pada penelitian ini terdistribusi normal dan homogen dengan nilai $\mathrm{p}>0,05$. Uji dilanjutkan dengan ANOVA-one way untuk melihat adanya kelompok yang berbeda bermakna.
Tabel 3.1 Hasil Pengukuran Volume dan Berat Rata-Rata Organ Ginjal Mencit

\begin{tabular}{|c|c|c|}
\hline \multirow[b]{2}{*}{ Kelompok } & \multicolumn{2}{|c|}{ Hasil } \\
\hline & $\begin{array}{c}\text { Volume } \\
\text { Ginjal (mL) }\end{array}$ & $\begin{array}{c}\text { Berat Ginjal } \\
(\mathrm{g})\end{array}$ \\
\hline K0 & $0,17 \pm 0,02$ & $0,149 \pm 0,015$ \\
\hline K1 & $0,18 \pm 0,02$ & $0,159 \pm 0,019$ \\
\hline $\mathrm{K} 2$ & $0,15 \pm 0,01$ & $0,141 \pm 0,010$ \\
\hline K3 & $0,16 \pm 0,02$ & $0,145 \pm 0,021$ \\
\hline $\mathrm{K} 4$ & $0,16 \pm 0,01$ & $0,139 \pm 0,012$ \\
\hline $\begin{array}{l}\text { Keterangan: } \\
\sum_{\mathrm{K} 0}=5 \\
\mathrm{~K} 1 \text { kontrol } \\
\mathrm{K} 2: \text { kontrol } \\
\mathrm{K} 3 \quad: 0,75 \mathrm{~g} / \mathrm{K} \\
\mathrm{K} 4: 1 \mathrm{~g} / \mathrm{Kg}\end{array}$ & $\begin{array}{l}\text { ormal (akuades } \\
5 \mathrm{~g} / \mathrm{Kg} \mathrm{BB} \\
\mathrm{g} \mathrm{BB} \\
\mathrm{B}\end{array}$ & ween 80) \\
\hline
\end{tabular}

Hasil uji menunjukkan bahwa secara umum data volume dan berat organ ginjal pada penelitian ini memiliki nilai $p>0,05$ yang menunjukkan bahwa tidak terdapat perbedaan bermakna antara kelompok kontrol dan kelompok perlakuan. Ringkasan hasil uji ANOVA-one way data volume dan berat organ ginjal mencit ditampilkan pada tabel 3.2.

Tabel 3.2 Ringkasan Hasil Uji ANOVA-One Way Data Volume dan Berat Organ Ginjal

\begin{tabular}{cc}
\hline Pengamatan & Nilai $p$ \\
\hline Volume Ginjal & 0.192 \\
Berat Ginjal & 0.381 \\
\hline
\end{tabular}

Keterangan: $*=p<0,05$ artinyya terdapat perbedaan signifikan

Hasil pengukuran berat dan volume ginjal dalam penelitian ini masih masuk ke dalam rentang normal, dimana berat ginjal dan volume rata-rata mencit jantan galur Balb/C dewasa normal adalah $0,113 \pm 0,0038 \mathrm{~g}$ sampai $0,161 \pm 0,0021 \mathrm{~g}$ dan $0,146 \mathrm{~mL}$ sampai 0,220 $\mathrm{mL}$, sehingga pemberian ekstrak etanol $70 \%$ daun A. scandens (L.) Moq. selama 30 hari tidak memberikan pengaruh yang signifikan terhadap volume dan berat organ ginjal mencit (Almajdub et al., 2007; Schiebi et al., 2013). 


\section{Samirana, dkk.}

Jurnal Farmasi Udayana, Vol6, No.2, Tahun 2017, 28-35

\subsection{Pengaruh Pemberian Ekstrak Etanol} 70\% Daun Binahong (A. scandens (L.) Moq.) terhadap Biokimia Ginjal Mencit Jantan Galur Balb/C

BUN dan kreatinin merupakan penanda spesifik untuk kerusakan fisiologis ginjal. Data hasil pengukuran kadar BUN dan kreatinin mencit ditampilkan pada tabel 3.3 dan gambar 3.1 serta 3.2.

Tabel 3.3 Rata-rata Hasil Pengukuran Kadar BUN dan Kreatinin Mencit pada Uji Toksisitas Subkronis Ekstraak Etanol 70\% Daun A. scandens (L.) Moq.

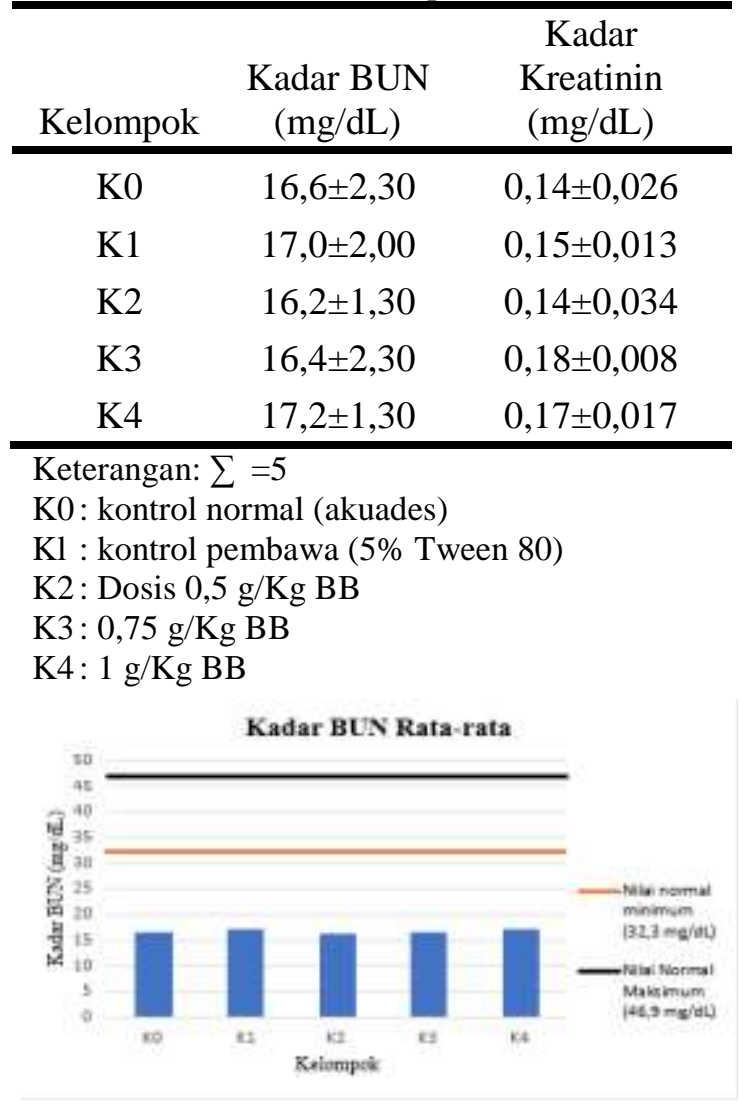

Gambar 3.1 Kadar BUN Rata-Rata Mencit Setelah Diberikan Ekstrak Etanol 70\% Daun A. scandens (L.) Moq. Selama 30 Hari

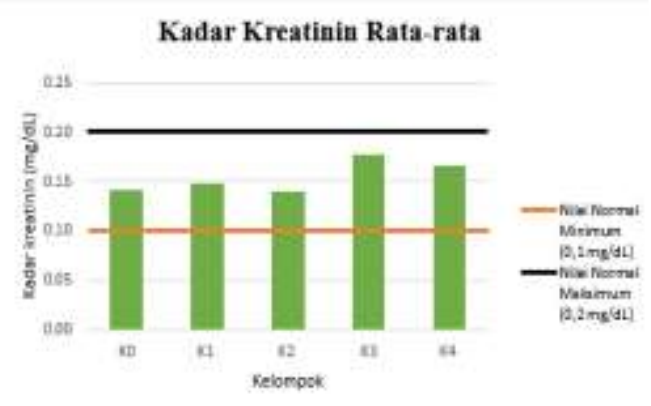

Gambar 3.2 Kadar Kreatinin Rata-Rata (B) Mencit Setelah Diberikan Ekstrak Etanol 70\% Daun A. scandens (L.) Moq. Selama 30 Hari
A. Kadar BUN

Data kadar BUN semua kelompok perlakuan diuji terlebih dahulu distribusinya dengan uji Shapiro-Wilk untuk melihat normalitas distribusi data dan Levene test untuk melihat homogenitas distribusi data. Data kadar BUN mencit pada penelitian ini terdistribusi normal dan homogen dengan nilai $\mathrm{p}>0,05$. Uji dilanjutkan dengan ANOVA-one way untuk melihat adanya kelompok yang berbeda bermakna. Hasil uji menunjukkan kadar BUN mencit pada penelitian ini memiliki nilai $\mathrm{p}>0,05$ artinya secara umum tidak terdapat perbedaan yang bermakna antara kelompok kontrol dan kelompok perlakuan. Ringkasan hasil uji ANOVA-one way data kadar BUN ditampilkan pada tabel 3.4 .

Tabel 3.4 Ringkasan Hasil Uji ANOVA-One Way Data Kadar BUN

\begin{tabular}{cc}
\hline \multicolumn{1}{c}{ Pengamatan } & Nilai $\mathrm{p}$ \\
\hline BUN & 0.913 \\
\hline $\begin{array}{l}\text { Keterangan: } *=\mathrm{p}<0,05 \\
\text { perbedaan signifikan }\end{array}$ & artinya terdapat
\end{tabular}

BUN atau urea merupakan metabolit utama yang berasal dari protein yang diekskresikan melalui ginjal, sehingga digunakan sebagai parameter untuk mengukur fungsi ginjal, jika kadarnya tinggi dalam darah maka fungsi ginjal terganggu (Hosten, 1990). Kadar BUN rata-rata dalam serum mencit yang diperoleh dalam penelitian ini tidak melewati batas normal kadar BUN serum mencit jantan galur Balb/C yaitu 32,3-46,9 $\mathrm{mg} / \mathrm{dL}$ dan berdasarkan hasil uji statistik menunjukkan bahwa tidak terdapat perbedaan yang signifikan antara kadar BUN mencit kelompok kontrol dengan kelompok yang diberikan ekstrak etanol $70 \%$ daun $A$. scandens (L.) Moq., sehingga pemberian ekstrak etanol $70 \%$ daun A. scandens (L.) Moq. tidak memberikan pengaruh yang signifikan terhadap fungsi ginjal mencit dilihat dari parameter kadar BUN serum (Menhlk, 2015).

B. Kadar Kreatinin

Data kadar kreatinin semua kelompok perlakuan diuji terlebih dahulu distribusinya dengan uji Shapiro-Wilk untuk melihat normalitas distribusi data dan Levene test untuk melihat homogenitas distribusi data. Data kadar kreatinin mencit pada penelitian ini terdistribusi normal dan homogen dengan nilai 


\section{Samirana, dkk.}

Jurnal Farmasi Udayana, Vol6, No.2, Tahun 2017, 28-35

$\mathrm{p}>0,05$. Uji dilanjutkan dengan ANOVA-one way untuk melihat adanya kelompok yang berbeda bermakna. Hasil uji menunjukkan kadar kreatinin mencit pada penelitian ini memiliki nilai $\mathrm{p}>0,05$ artinya secara umum tidak terdapat perbedaan yang bermakna antara kelompok kontrol dan kelompok perlakuan. Ringkasan hasil uji ANOVA-one way data kadar kreatinin ditampilkan pada tabel 3.5.

Tabel 3.5 Ringkasan Hasil Uji ANOVA-One Way Data Kadar Kreatinin

\begin{tabular}{cc}
\hline \multicolumn{1}{c}{ Pengamatan } & Nilai $\mathrm{p}$ \\
\hline \multicolumn{1}{c}{ Kreatinin } & 0.122 \\
\hline $\begin{array}{l}\text { Keterangan: } \quad *=\mathrm{p}<0,05 \\
\text { perbedaan signifikan }\end{array}$ & artinya $\quad$ terdapat
\end{tabular}

Kreatinin merupakan produk katabolisme kreatin otot yang diekskresikan melalui ginjal, jika kadarnya tinggi dalam darah maka dapat diindikasikan adanya gangguan fungsi ginjal (Hosten, 1990). Kadar kreatinin rata-rata dalam serum mencit yang diperoleh dalam penelitian ini tidak melewati batas normal kadar kreatinin serum mencit jantan galur Balb/C yaitu 0,1-0,2 mg/dL dan berdasarkan hasil uji statistik menunjukkan bahwa tidak terdapat perbedaan yang signifikan antara kadar kreatinin mencit kelompok kontrol dengan kelompok yang diberikan ekstrak etanol $70 \%$ daun A. scandens (L.) Moq., sehingga pemberian ekstrak etanol $70 \%$ daun A. scandens (L.) Moq. tidak memberikan pengaruh yang signifikan terhadap fungsi ginjal mencit dilihat dari parameter kadar kreatinin serum (Menhlk, 2015).

\section{KESIMPULAN}

Pemberian ekstrak etanol $70 \%$ daun $A$. scandens (L.) Moq. selama 30 hari secara per oral, tidak memberikan pengaruh yang signifikan terhadap makroskopik ginjal mencit dilihat dari berat dan volume ginjal, serta tidak memberikan pengaruh yang signifikan terhadap biokimia darah dilihat dari parameter kadar BUN dan kreatinin darah.

\section{DAFTAR PUSTAKA}

Almajdub, M., Magnier, L., Juillard, L., and Janier, M. 2007. Kidney Volume Quantification Using ContrastEnhanced in Vivo X-Ray Micro-CT in
Mice. Contrast Media Mol. Imaging. Vol.3: 120-126.

BPOM. 2004. Keputusan Kepala Badan Pengawas Obat Dan Makanan Republik Indonesia Nomor Hk. 00.05.4.2411 tentang Ketentuan Pokok Pengelompokan dan Penandaan Obat Bahan Alam Indonesia. Jakarta: Badan Pengawas Obat dan Makanan Republik Indonesia

Campbell, N. A., Reece, J. B., dan Mitchell, L. G. 2003. Biology Edisi ke-5. Jilid 3. Jakarta: Erlangga.

Gowda, S., Desai, P.B., Kulkarni, S.S., Hull, V.V., Math, A.A.K., and Vernekar SN. 2010. Markers of Renal Function Tests. N Am J Med Sci. Vol. 2(4): 170173.

Depkes RI. 1995. Materia Medika Indonesia Jilid VI. Jakarta: Departemen Kesehatan Republik Indonesia.

Depkes RI. 2011. Farmakope Herbal Indonesia Edisi II. Jakarta: Departemen Kesehatan Republik Indonesia

Daramita, N. K. A. C. 2011. "Uji Toksisitas Akut dan Sub Akut Ekstrak Etanol 95\% Daun Binahong Anredera scandens (L.) Moq pada Mencit Jantan Galur Balb/C)" (skripsi). Denpasar: Universitas Udayana.

Erawati, W.T. 2011. "Uji Aktivitas Antitukak Fraksi N-Heksan Daun Binahong (Anredera scandens (L.) Moq.) pada Tikus Putih Jantan Galur Sprague Dawley". (skripsi). Denpasar: Universitas Udayana.

Feybriyanti, Y. W. 2011. "Uji Aktivitas Antiinflamasi Ekstrak N-Heksan, Kloroform dan Etanol Daun Binahong (Anredera scandens (L.) Moq.) pada Tikus yang Diinduksi Karagenan 1\%" (skripsi). Denpasar: Universitas Udayana.

Fitria, A. 2009. "Uji aktivitas Antibakteri Ekstrak Daun Anredera cordifolia 


\section{Samirana, dkk.}

Jurnal Farmasi Udayana, Vol6, No.2, Tahun 2017, 28-35

(Tenore) Steen, Anredera scandens (L.) Moq., Basella rubra L. pada Bakteri Gram Positif dan Bakteri Gram Negatif" (skripsi). Denpasar: Universitas Udayana.

Hariana, A. 2013. 262 Tumbuhan Obat dan Khasiatnya. Jakarta: Penebar Swadaya.

Hosten, A.O. 1990. The History, Physical, and Laboratory Examinations, Clinical Methods, 3rd edition. Atlanta: Emory University School of Medicine.

Jothy, S.L., Zakaria, Z., Chen, Y., Lau, Y.L., Latha, L.Y., and Sasidharan, S. 2011. Acute Oral Toxicity of Methanolic Seed Extract of Cassia fistula in Mice. Molecules. Vol.16: 5268-5282.

Karismawan, P. N. 2013. "Profil Kandungan Kimia dan Uji Aktivitas Antiluka Bakar Ekstrak Etanol Daun Binahong (Anredera scandens (L.) Moq.) Pada Tikus Jantan Galur Sprague Dawley" (skripsi). Denpasar: Universitas Udayana.

Menlhk. 2015. Peraturan Menteri Lingkungan Hidup dan Kehutanan Republik Indonesia Nomor P.55/MenlhkSetjen/2015 Tentang Tata Cara Uji Karakteristik Limbah Bahan Berbahaya Dan Beracun. Jakarta: Menteri Lingkungan Hidup dan Kehutanan Republik Indonesia.

Michael, M., Yano, B., Sellers, R.S., Perry, R., Morton, D., Roome, N., Johnson, J.K., and Schafer, K. 2007. Evaluation of Organ Weights for Rodent and NonRodent Toxicity Studies: A Review of Regulatory Guidelines and a Survey of Current Practices. Toxicologic Pathology. Vol. 35:742-750.

Nirogi, R., Goyal, V.K., Jana, S., Pandey, S.K., and Gothi, A. 2014. What Suits Best for Organ Weight Analysis: Review of Relationship Between Organ Weight and Body / Brain Weight for Rodent Toxicity Studies. International Journal of
Pharmaceutical Sciences and Research. Vol. 5(4): 1525-1532.

Ping, K.Y., Darah, I., Chen, Y., Sreeramanan, S., and Sasidharan, S., 2013. Acute and Subchronic Toxicity Study of Euphorbia hirta L. Methanol Extract in Rats. BioMed Research International. Vol. 13: 1-14.

Purwanti, D. H. 2011. "Uji Aktivitas Antitukak Fraksi Kloroform Daun Binahong (Anredera scandens (L.) Moq.) pada Tikus Putih Jantan Galur Sprague Dawley" (skripsi). Denpasar: Universitas Udayana.

Schiebi, I.M., Bardehle, S., and Castrop, H. 2013. Superficial Nephrons in BALB/c and C57BL/6 Mice Facilitate In Vivo Multiphoton Microscopy of the Kidney. PLOS One. Vol. 8: 1-10.

Samirana, P. O., Leliqia, N. P. E., dan Ariantari, N. P. 2014. TLCDensitometer Profile and Antiulcer Activity Assay of Ethanol Extract of Binahong Leaves (Anredera scandens (L.) Moq.) in Sprague dawley Strain Male Rats. Proceeding The International Conference Pharmaceutical Care 2014 New Development of Pharmaceutical Care in a Pharmacogenetic and Pharmacogenomic Approach. Malang: Universitas Muhammadyah.

Sellers, R.S., Morton, D., Michael, B., Roome, N., Johnson, J.K., Yano, B.L., Perry, R., and Schafer. K. 2007. Society of Toxicologic Pathology Position Paper: Organ Weight Recommendations for Toxicology Studies. Toxicologic Pathology. Vol. 35:751-755.

Subratha, I. D. G.P. Y. 2016. "Profil Kromatografi Kandungan Fitokimia dan Aktivitas Epitelisasi Ekstrak Etanol Daun Binahong (Anredera scandens (L.) Moq.) pada Penyembuhan Luka Eksisi” (skripsi). Denpasar: Universitas Udayana.

Wardhani, L. K., dan Sulistyani, N. 2012. Uji Aktivitas Antibakteri Ekstrak Etil 
Samirana, dkk.

Jurnal Farmasi Udayana, Vol6, No.2, Tahun 2017, 28-35

Asetat Daun Binahong (Anredera

scandens (L.) Moq.) terhadap Shigella

fexneri Beserta Profil Kromatografi

Lapis Tipis. Jurnal Ilmiah

Kefarmasian. Vol. 2 (1): 1-16. 